\title{
KIR2DL5 mutation and loss underlies sporadic dermal neurofibroma pathogenesis and growth
}

\author{
Corina Anastasaki ${ }^{1}$, Sonika Dahiya ${ }^{2}$ and David H. Gutmann ${ }^{\mathbf{1}}$ \\ ${ }^{1}$ Department of Neurology, Washington University School of Medicine, St. Louis, MO 63110, USA \\ ${ }^{2}$ Department of Pathology, Washington University School of Medicine, St. Louis, MO 63110, USA \\ Correspondence to: David H. Gutmann, email: gutmannd@wustl.edu
}

Keywords: sporadic neurofibroma, Schwann cells, KIR2DL5, tumor suppressor gene, RAS/AKT/mTOR signaling

Received: December 28, $2016 \quad$ Accepted: April 24, $2017 \quad$ Published: May 10, 2017

Copyright: Anastasaki et al. This is an open-access article distributed under the terms of the Creative Commons Attribution License 3.0 (CC BY 3.0), which permits unrestricted use, distribution, and reproduction in any medium, provided the original author and source are credited.

\section{ABSTRACT}

Dermal neurofibromas (DNFs) are benign peripheral nerve sheath tumors thought to originate from Schwann cell progenitors. These tumors represent one of the hallmarks of the neurofibromatosis type 1 (NF1) tumor predisposition syndrome, where they can number in the thousands. While NF1-DNFs arise due to mutations in the NF1 gene, the vast majority of DNFs occur sporadically (sp-DNFs), where the genetic etiology is currently unknown. Herein, we employed whole-exome sequencing of sp-DNFs to identify a recurrent mutation in the KIR2DL5 gene, which codes for a protein suppressor of natural killer (NK) cell activity. While the function of KIR2DL5 outside of the immune system is unknown, we identified a KIR2DL5 ${ }^{\mathrm{N} 173 \mathrm{D}}$ mutation in three of nine sp-DNFs, resulting in loss of KIR2DL5 protein expression. In contrast, two of these subjects had unrelated tumors, which retained KIR2DL5 protein expression. Moreover, loss of KIR2DL5 expression was demonstrated in $\mathbf{1 5}$ of $\mathbf{4 5}$ independentlyidentified sp-DNFs. Consistent with its potential role as a negative growth regulator important for neurofibroma maintenance, ectopic KIR2DL5 ${ }^{\mathrm{N} 173 \mathrm{D}}$ expression in normal human Schwann cells resulted in reduced KIR2DL5 expression and increased cell proliferation. Similarly, KIR2DL5 short hairpin RNA knockdown (KD) decreased KIR2DL5 protein levels and increased cell proliferation, as well as correlated with PDGFR $\beta$ and downstream RAS/AKT/mTOR hyperactivation. Importantly, inhibition of PDGFR $\beta$ or AKT/mTOR activity in KIR2DL5-KD human Schwann cells reduced proliferation to control levels. Collectively, these findings establish KIR2DL5 as a new Schwann cell growth regulator relevant to sp-DNF pathogenesis, which links sporadic and NF1-associated DNFs through RAS pathway hyperactivation.

\section{INTRODUCTION}

Dermal neurofibromas (DNFs) are common lowgrade peripheral nerve sheath tumors [1], which are hypothesized to arise from Schwann cell progenitors [2-4]. While these tumors do not undergo malignant transformation, they can be painful or number in the thousands, as seen in some adults with the neurofibromatosis type 1 (NF1; OMIM: 613113) cancer predisposition syndrome. Nearly all adults with NF1 manifest DNFs, which result from bi-allelic inactivation of the NF1 tumor suppressor gene and loss of NF1 protein (neurofibromin) expression [5-7]. This bi-allelic
$N F 1$ loss reflects a combination of a germline $N F 1$ gene mutation and the acquisition of a somatic NF1 mutation in Schwann cell lineage populations [3, 4]. As a RASGTPase-activating protein (RAS-GAP), neurofibromin loss in Schwann cells leads to increased RAS activation [8-10] and downstream mechanistic target of rapamycin (mTOR)-mediated hyperproliferation [11-14].

While NF1 mutations characterize NF1-DNFs, the majority of DNFs occurs in the absence of NF1. These sporadic DNFs (sp-DNFs) are histologically identical to their NF1-associated counterparts, and most often arise as solitary dermal tumors. Since these tumors are encountered in individuals lacking other features supportive of a 
clinical diagnosis of NF1, they do not harbor NF1 gene mutations. As such, it is currently not known what genetic mutations are responsible for the genesis of sp-DNFs. In an effort to identify potential molecular etiologies for these non-syndromal benign nerve sheath tumors, we performed whole exome sequencing on a series of NF1-associated and sporadic dermal neurofibromas.

\section{RESULTS AND DISCUSSION}

In order to identify potential molecular etiologies for sporadic DNFs (sp-DNFs), we examined a cohort of 17 male patients (7 NF1-DNFs and 10 sp-DNFs) by whole-exome sequencing. Using this approach, NF1 gene mutations were detected in 5/7 NF1-DNFs, and surprisingly, 1/10 (Sp7) sp-DNFs where the identified point mutation is predicted to result in a splicing variant of the NF1 transcript (Figure 1A, 1B). The inability to detect mutations in two of the NF1-DNFs likely reflects the insensitivity of exome sequencing to identify intronic mutations or large-gene deletions, both common mutational types in NF1 $[15,16]$. However, consistent with a clinical diagnosis of NF1 or the presence of a NF1 gene mutation, immunohistochemical staining confirmed loss of neurofibromin expression in the $\mathrm{Sp} 7$ tumor and in all NF1-DNFs (Figure 1C, Supplementary Figure 1). Subject Sp7 was lost to follow-up, and may have undiagnosed NF1 or harbored a tumor that underwent bi-allelic NF1 gene inactivation [17]. Conversely, all sp-DNFs without an identified NF1 mutation, as well as an independent cohort of 45 unrelated sp-DNFs retain neurofibromin expression (Supplementary Figure 1), consistent with exclusion of NF1 as a clinical diagnosis.

While 105 genes with exonic nucleotide variations (frameshift insertions/deletions, missense, and nonsense mutations; Supplementary Table 1) were identified in more than one DNF, eight genes were mutated in at least four DNFs $(>22.22 \%$ of the cohort; Figure 1D, Supplementary Figure 2). These mutated genes did not separate sporadic or NF1-associated DNFs into clear subgroups; however, the specific nucleotide alterations identified in 6 of the 8 genes were identical in all of the tumors examined (Figure 1E). Importantly, three of these mutations have also been reported in other cancers (cBioPortal; www.cbioportal. org), suggesting potential importance in DNF pathogenesis that could be pursued beyond the scope of this study.

While no mutations were found in genes commonly mutated in a related peripheral nerve sheath tumor (schwannoma; NF2 [18, 19], LZTR1 [20, 21], SMARCB1 $[22,23]$ genes), recurrent mutations in the KIR2DL5 gene were identified only in the sp-DNFs (three of nine sp-DNFs examined). KIR $2 D L 5$ is a gene unique to primates, and is not found in cattle or mice [24]. Of note, the particular KIR2DL5 mutation (Asn173Asp, N173D; 3/9 tumors) resulted in a non-conservative change in an evolutionarilyconserved residue (Figure 2A) within a predicted immunoglobulin-like domain [25] (Supplementary Figure $3 \mathrm{~A})$. In the three KIR2DL5 ${ }^{\mathrm{N} 173 \mathrm{D}}$-mutant sp-DNFs, immunohistochemistry revealed no appreciable KIR2DL5 protein expression, whereas human tonsil, normal human sural nerve, and all NF1-DNFs examined expressed KIR2DL5 (Figure 2B). To determine whether loss of KIR2DL5 protein expression correlated with the presence of a KIR2DL5 ${ }^{\mathrm{N} 173 \mathrm{D}}$ mutation, we examined two unrelated tumors (Sp5: basal cell carcinoma, Sp6: keratinous cyst) isolated from two of the three subjects with this mutation in their DNFs (Figure 2B). Both non-DNF tissues were immunopositive for KIR2DL5, suggesting that $K I R 2 D L 5^{\mathrm{N} 173 \mathrm{D}}$ is likely a DNF-specific mutation. Moreover, in an independent cohort of sp-DNFs, $15 / 45$ tumors were KIR2DL5-immunonegative (33\%; Figure 2B, Supplementary Figure 3B), further supporting the hypothesis that KIR2DL5 expression loss is specific to spDNFs and likely is caused by the KIR $2 D L 5^{\mathrm{N} 173 \mathrm{D}}$ mutation.

To determine whether the KIR $2 D L 5^{\mathrm{N} 173 \mathrm{D}}$ mutation was responsible for the reduction in KIR2DL5 protein expression observed, normal human Schwann cells were infected with either KIR2DL5 $5^{\mathrm{WT}}$ or KIR $2 D L 5^{\mathrm{N} 173 \mathrm{D}}$ viral expression constructs (Figure 2D). Whereas wild-type KIR2DL5 expression was easily detected by Western blot and promoted a minor increase in Schwann cell growth (1.18-fold increase compared to PLKO-infected Schwann cells), KIR2DL5 $5^{\mathrm{N} 173 \mathrm{D}}$ mutant-expressing cells exhibited a $36.9 \%$ decrease in KIR2DL5 expression, a 1.88fold increase in cell proliferation (BrdU incorporation) (Figure 2E), and a 1.5-fold increase in total cell numbers (Figure 2F) relative to KIR2DL5 ${ }^{\mathrm{WT}}$ expressing cells. Together, these data demonstrate that the KIR2DL $5^{\mathrm{N} 173 \mathrm{D}}$ mutation functions in a dominant negative manner to regulate KIR2DL5 expression and Schwann cell growth.

KIRs were initially discovered on the surface of natural killer (NK) cells [26], where they have been reported to mediate the immune response of NK cells and a subset of T lymphocytes against infection and cancer [27-29]. While KIR2DL5 is an orphan receptor with no known ligands, its phosphorylation in NK cells recruits the Src homology region 2-containing protein tyrosine phosphatase-2 (SHP-2) molecule, resulting in activation of downstream signaling pathways. Since the role of KIR2DL5 has not been previously explored in non-immune system cells, we first demonstrated that KIR2DL5 is expressed in S100 $\beta^{+}$ Schwann cells within normal human peripheral (sural) nerve by immunofluorescence (Figure 2C), and in normal human Schwann cells by western blot (CTL; Figure 2D) and immunofluorescence (Supplementary Figure 4A). While the majority of the KIR2DL5 expression in both normal sural nerve and immunopositive sDNFs was found in the Schwann cell compartment, there was also expression in other cell types. In this regard, co-labelling of KIR2DL5 ${ }^{+}$ cells with mast cell (tryptase, c-Kit) and fibroblast (vimentin)-specific antibodies (Supplementary Figure 4) revealed that the few remaining KIR2DL5-immunoreactive 
cells in the Sp4, Sp5 and Sp6 DNF tumor specimens were stromal elements.

As a complementary approach to expressing the mutant KIR2DL5 gene in normal human Schwann cells to reduce KIR2DL5 expression, endogenous
KIR2DL5 expression was also decreased by RNA (shRNA) interference. Since KIR2DL5 is encoded by two genes, KIR2DL5A (OMIM: 605305) and KIR2DL5B (OMIM: 615727) that are $>99 \%$ sequence identical [25], three independently-generated short-
A

\begin{tabular}{|c|c|c|c|}
\hline Tumor & Sex & NF1 mutation & Protein alteration \\
\hline NF1-1 & Male & not detected & \\
\hline NF1-2 & Male & c.1546delC & p.P516fs \\
\hline NF1-3 & Male & not detected & \\
\hline NF1-4 & Male & c.3183delA & p.V1061fs \\
\hline NF1-5 & Male & c.3529C>T & p.Q1174X \\
\hline NF1-6 & Male & c.5107C>T & p.Q1703X \\
\hline NF1-7 & Male & c.910C>T & p.R304X \\
\hline S1 & Male & not detected & \\
\hline S2 & Male & not detected & \\
\hline S3 & Male & not detected & \\
\hline S4 & Male & not detected & \\
\hline S5 & Male & not detected & \\
\hline S6 & Male & not detected & \\
\hline S7 & Male & c.6642A>T & p.T2087S \\
\hline S8 & Male & not detected & \\
\hline S9 & Male & not detected & \\
\hline S10 & Male & not detected & \\
\hline
\end{tabular}

B

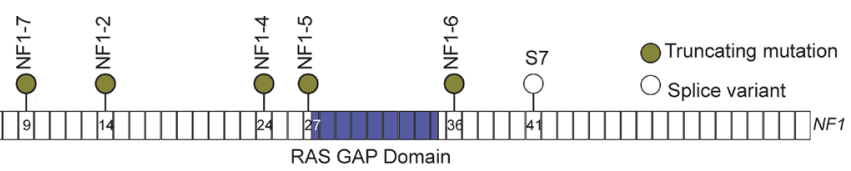

C

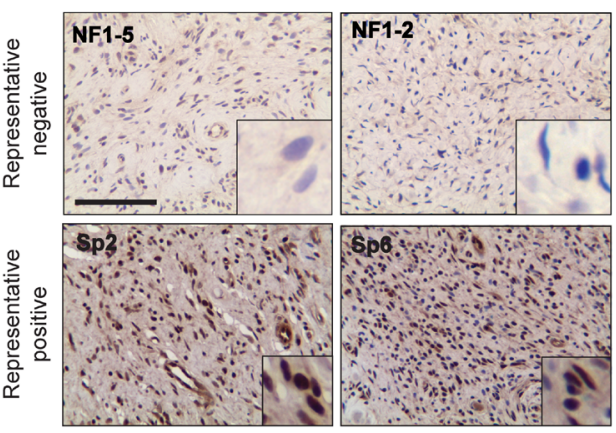

\begin{tabular}{|c|c|c|c|c|c|c|c|}
\hline \multirow{2}{*}{ Gene } & \multirow[b]{2}{*}{$\begin{array}{l}\text { Chromosome } \\
\text { location }\end{array}$} & & & \multirow[b]{2}{*}{$\begin{array}{l}\text { \# of mutations } \\
\text { in gene }\end{array}$} & \multirow[b]{2}{*}{$\begin{array}{l}\text { \# of mutations in } \\
\text { conserved domain }\end{array}$} & \multicolumn{2}{|c|}{ NF1 mutation No NF1 mutation } \\
\hline & & $\begin{aligned} \# \text { of } t \\
\mathrm{mu}\end{aligned}$ & $\begin{array}{l}\text { mors with } \\
\text { ation (\%) }\end{array}$ & & & 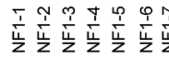 & ஸั \\
\hline MAML3 & $4 q 31.1$ & 10 & (58.8\%) & 1 & 1 & & \\
\hline TAS2R3O & $12 p 13.2$ & 9 & (52.9\%) & 1 & 1 & & \\
\hline DNAH3 & 16p. 12.3 & 4 & $(23.5 \%)$ & 4 & 2 & & \\
\hline KIAA0040 & $1 \mathrm{q} 25.1$ & 4 & $(23.5 \%)$ & 1 & 1 & & \\
\hline NDUFS7 & $19 \mathrm{p} 13.3$ & 4 & (23.5\%) & 1 & 1 & & \\
\hline TAS2R31 & $12 \mathrm{p} 13.2$ & 4 & $(23.5 \%)$ & 2 & 2 & & \\
\hline SSPO & $7 q 36.1$ & 4 & $(23.5 \%)$ & 4 & 3 & & \\
\hline UBXN11 & $1 p 36.11$ & 4 & $(23.5 \%)$ & 1 & 0 & & \\
\hline
\end{tabular}

E

\begin{tabular}{|c|c|c|c|c|c|c|c|}
\hline 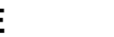 & & & & & & & NF1 mutation \\
\hline Gene & $\begin{array}{l}\text { Genomic } \\
\text { mutation }\end{array}$ & $\begin{array}{l}\text { Protein } \\
\text { alteration }\end{array}$ & $\begin{array}{c}\text { \# of tumors } \\
(\%)\end{array}$ & $\begin{array}{c}\% \text { of } N F 1 \\
\text { tumors }\end{array}$ & $\begin{array}{l}\% \text { of Sporadic } \\
\text { tumors }\end{array}$ & $\begin{array}{l}\text { Recurrence in } \\
\text { cancer }\end{array}$ & 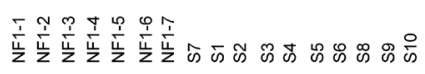 \\
\hline MAML3 & c.1513_1514del & p.Q505fs & $10(58.8 \%)$ & $71.4 \%(5)$ & $50 \%(5)$ & none & \\
\hline TAS2R30 & c.C142G & p.L48V & $9(52.9 \%)$ & $42.9 \%(3)$ & $60 \%(6)$ & $\begin{array}{l}\text { thymic epithelial } \\
\text { tumor }\end{array}$ & \\
\hline KIAA0040 & c.C195A & p.N65K & $4(23.5 \%)$ & $28.6 \%(2)$ & $20 \%(2)$ & $\begin{array}{l}\text { renal clear cell } \\
\text { carcinoma }\end{array}$ & \\
\hline NDUFS7 & c. G504T & p.R168S & $4(23.5 \%)$ & $28.6 \%(2)$ & $20 \%(2)$ & none & \\
\hline TAS2R31 & c. C814T & p.P272S & $4(23.5 \%)$ & $14.3 \%(1)$ & $30 \%(3)$ & none & \\
\hline UBXN11 & c.A1480T & p.S494C & $4(23.5 \%)$ & $28.6 \%(2)$ & $20 \%(2)$ & $\begin{array}{c}\text { diffuse large } \\
\text { B-cell lymphoma }\end{array}$ & \\
\hline
\end{tabular}

Figure 1: NF1 gene mutation and neurofibromin expression stratify DNFs into two subgroups. (A) List of detected $N F 1$ gene mutations and predicted protein alterations. (B) Schematic representation of $N F 1$ gene mutations. (C) Representative images depicting decreased neurofibromin expression in tumors with NF1 mutations compared to sp-DNFs. Scale bar, $25 \mu$ m. (D) Genes recurrently mutated in more than four DNFs. (E) Recurrent mutations identified in more than four DNFs. Black boxes = mutation. 
hairpin RNA molecules were employed to target both genes. Following Schwann cell infection, 76.78\% (sh\#1; TCTCTCCATGACTCACCCTAT), $\quad 88.29 \%$ (sh\#2; CAGGAGCTCATTTGACATGTA) and 76.32\% (sh\#3; GAAACTCTTCAAGTAGTTCAT) KIR2DL5 knockdown was achieved (Figure 3A), leading to 2.2,
3.2- and 2.7-fold increases in cell number, respectively (direct cell counting; Figure 3B) relative to GFP-vectorinfected cells (CTL). This increase in cell numbers represented a $2.7-(\operatorname{sh} \# 1), 2.83-(\operatorname{sh} \# 2)$, and $3-(\operatorname{sh} \# 3)$ fold increase in proliferation (BrdU incorporation; Figure 3C), with no change in apoptosis (TUNEL staining;

A

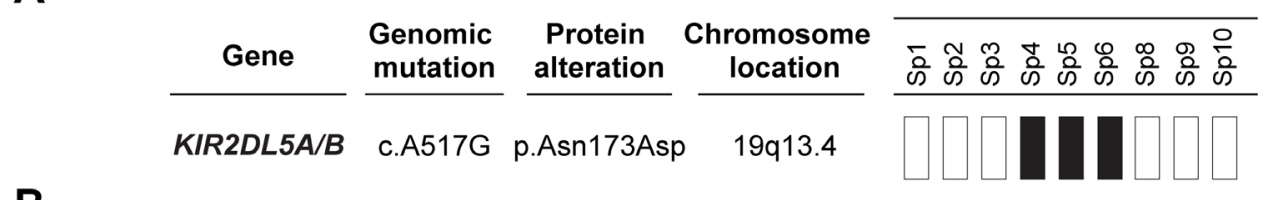

B
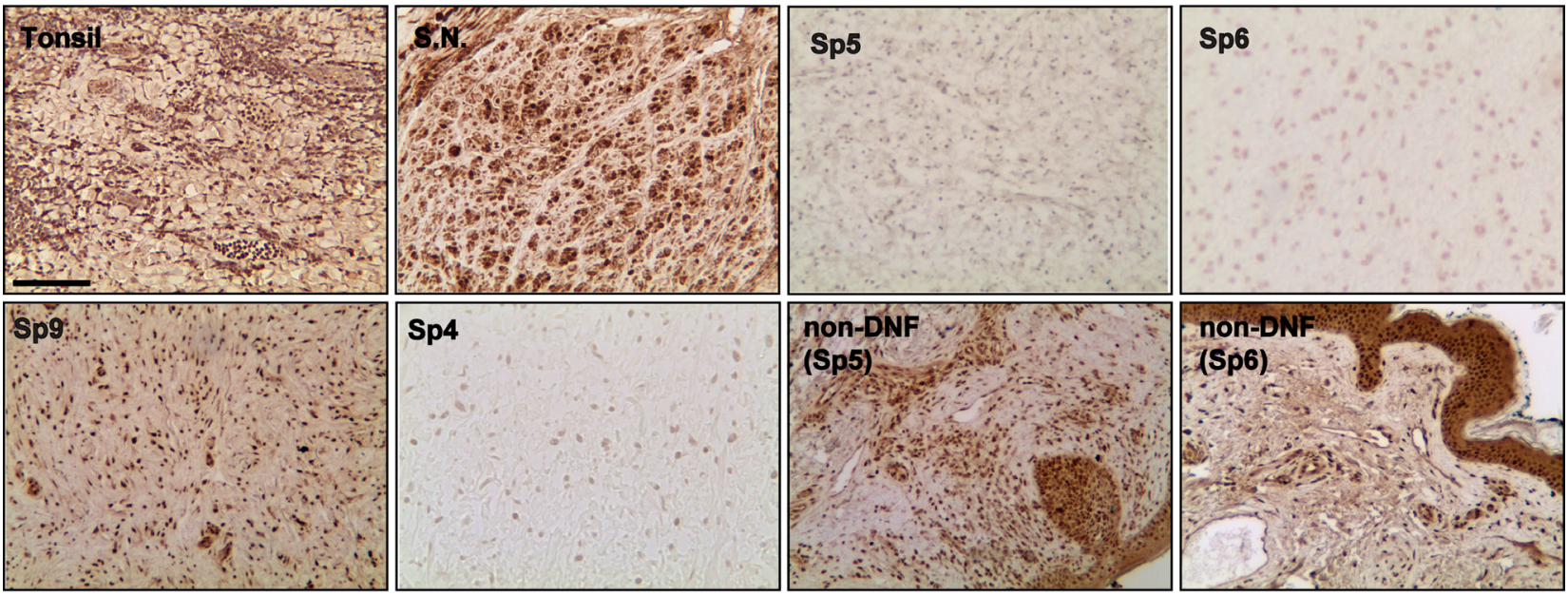

C
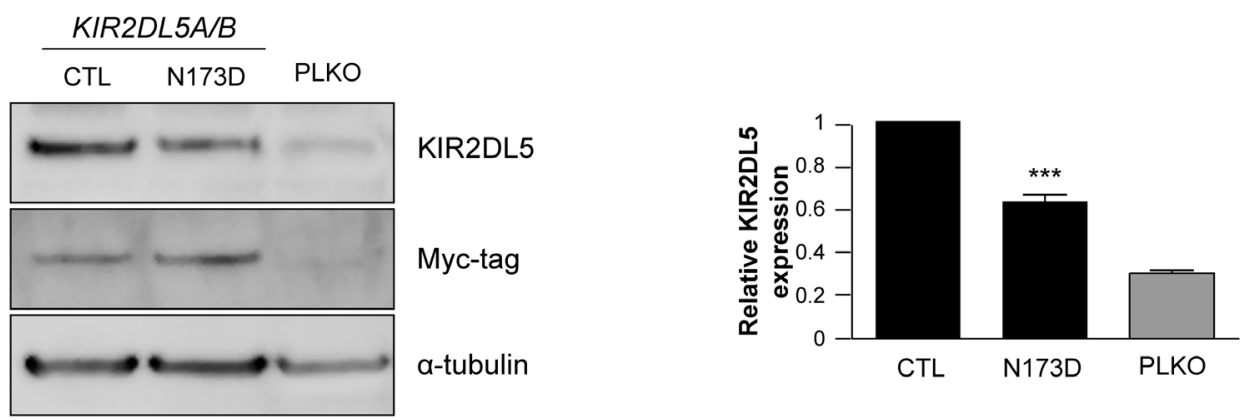

D

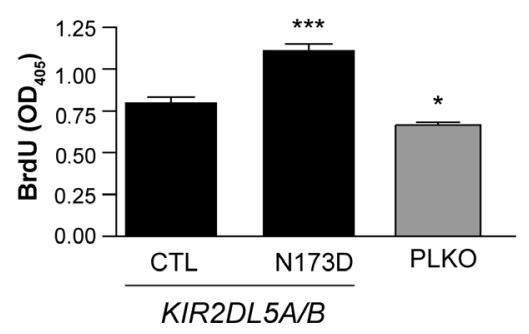

E

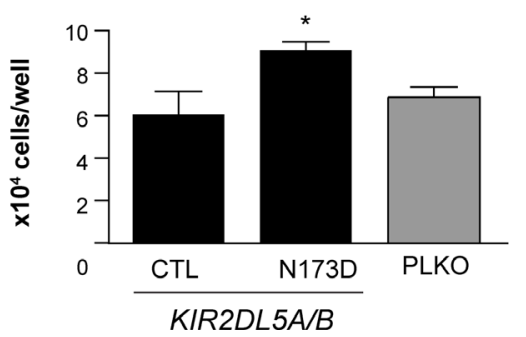

Figure 2: KIR2DL5 ${ }^{\mathrm{N} 173 \mathrm{D}}$ mutation reduces KIR2DL5 expression. (A) 3/9 sp-DNFs harbor the KIR2DL5 ${ }^{\mathrm{N} 173 \mathrm{D}}$ mutation. (B) KIR2DL5 mutation is associated with decreased KIR2DL5 protein levels in sp-DNFs but not NF1-DNFs or non-DNF tissue. Tonsil and sural nerve (S.N.) were used as controls. (C) KIR2DL $5^{\mathrm{N} 173 \mathrm{D}}$ expression results in reduced KIR2DL5 levels, as demonstrated with a myc antibody

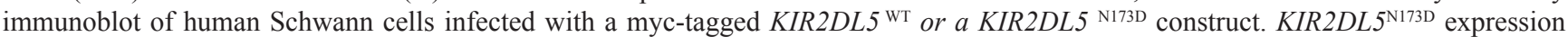
results in increased (D) cell proliferation and (E) cell number relative to KIR2DL5 ${ }^{\mathrm{wT}}$ control-infected Schwann cells. PLKO-GFP-control (PLKO)-infected cells are shown for comparison. Data are represented as means of three independent infections/over-expression construct \pm s.e.m. One-way ANOVA was used for statistical analysis. ${ }^{*} p<0.05 ; * * p<0.001$. Scale bar $50 \mu \mathrm{m}$. 
Supplementary Figure 3C). Expression of control KIR2DL5 engineered so as not to be targeted by these shRNA constructs following shRNA knockdown restored KIR2DL5 expression, as well as cell proliferation and cell numbers (Supplementary Figure 3D-3F).

Since RAS-dependent signaling is enhanced in NF1DNFs, the activation status of RAS (RAS-GTP) and RASregulated pathways were examined. Following KIR2DL5 knockdown $\left(K I R 2 D L 5 A / B^{\mathrm{KD}}\right)$, there was a 3.5- $(\operatorname{sh} \# 1)$, 4.7$(\mathrm{sh} \# 2)$, and 2.9- $(\mathrm{sh} \# 3)$ fold increase in RAS activation (RAS-GTP; Figure 4A). While others have shown that NF1-DNF growth depends on ERK1/2 pathway activation $[30,31]$, KIR $2 D L 5$ reduction had no effect on ERK1/2 ${ }^{\text {Thr202 }}$ Tyr204 phosphorylation (activation; Supplementary Figure $5 \mathrm{~A}-5 \mathrm{D})$, but rather led to increased AKT activation $\left(\mathrm{AKT}^{\mathrm{Thr} 308}\right.$ and $\mathrm{AKT}^{\mathrm{Ser} 473}$ phosphorylation; sh\#1, 31.5-fold and 2.8-fold; sh\#2, 19.6-fold and 5.9-fold; sh\#3, 15.6fold and 7.3-fold, respectively; $n=3$ ), as well as elevated mTOR activation (S6 ${ }^{\text {Ser240/244 }}$ phosphorylation; sh\#1, 3.2fold; sh\#2, 4.9-fold; sh\#3, 7.2-fold; $n=3$ ) (Figure 4A). Similarly, expression of the mutant KIR2DL5 protein (KIR2DL5 N173D) resulted in 2.24-fold and 1.78-fold increases in AKT and S6 phosphorylation, respectively (Supplementary Figure 3).

To demonstrate that KIR2DL5 regulates cell proliferation in an AKT/mTOR-dependent fashion, we initially employed an AKT-specific inhibitor (MK2206). Following a 4h MK2206 treatment of control- and shRNA-infected Schwann cells, AKT ${ }^{\text {Ser473 }}$ phosphorylation (sh\#1, 0.9; sh\#2 0.95; sh\#3 0.97-fold), as well as the phosphorylation of two of its downstream effectors S6 (sh\#1, 0.4; sh\#2 0.6; sh\#3 0.5-fold) and PRAS40 (sh\#1,
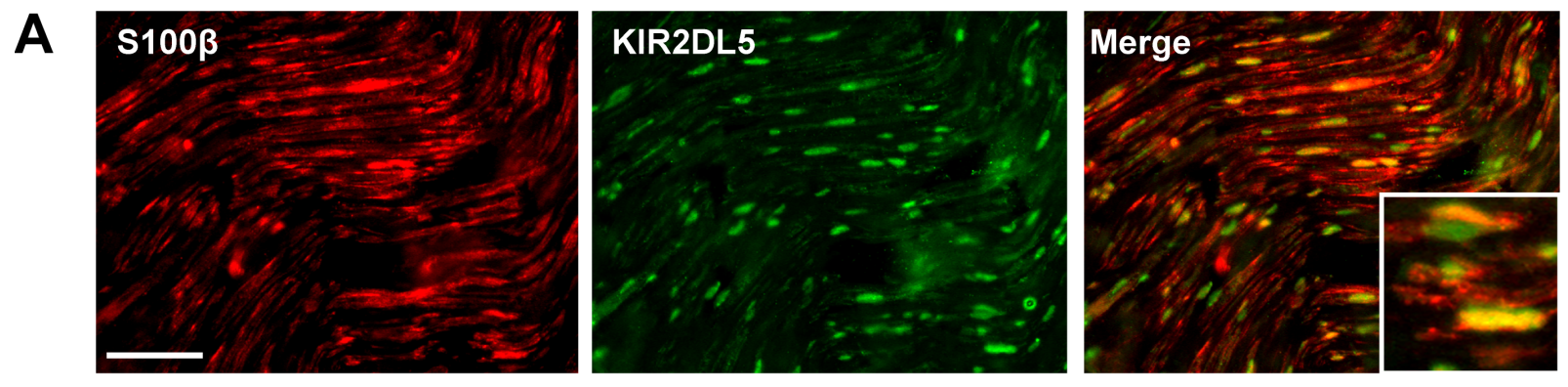

B
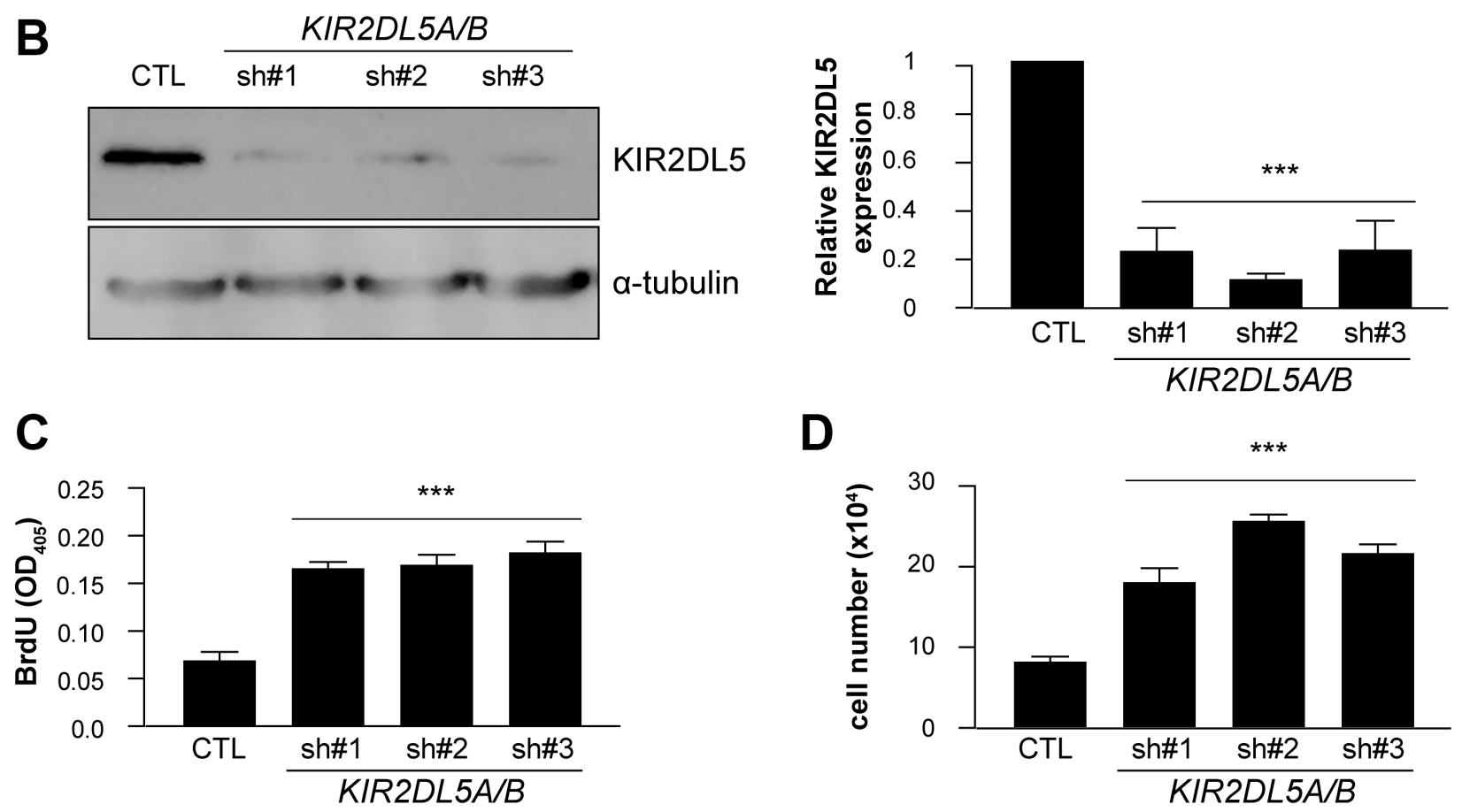

Figure 3: KIR2DL5 is a negative Schwann cell growth regulator. (A) Co-localization of KIR2DL5 with S100 $\beta^{+}$Schwann cells in normal human sural nerve. b. shRNA silencing of KIR2DL5A/B expression in normal human Schwann cells, where $K I R 2 D L 5 A / B K D$ cell KIR2DL5 expression levels were calculated by normalizing the relative KIR2DL5/ $\alpha$-tubulin band intensity ratio to that of GFP-controlinfected Schwann cells. (B) western blot). KIR2DL5A/BKD results in increased (C) cell number and (D) proliferation relative to GFPinfected serum-starved Schwann cells. Data are represented as means of three independent infections/shRNA construct \pm s.e.m. One-way ANOVA with Bonferroni correction was used for statistical analysis. ***p $<0.001$. Scale bar $25 \mu \mathrm{m}$. 
$0.7 ; \operatorname{sh} \# 2,1.3 ; \mathrm{sh} \# 3,1.2$-fold), were reduced to control levels (Figure 4B). Additionally, AKT inhibition restored cell numbers (Figure 4C) and proliferation (Figure 4D) to normal levels. Next, to determine whether mTOR inhibition could similarly reverse the effects of KIR2DL5 KD, shRNA-infected Schwann cells were treated with

A
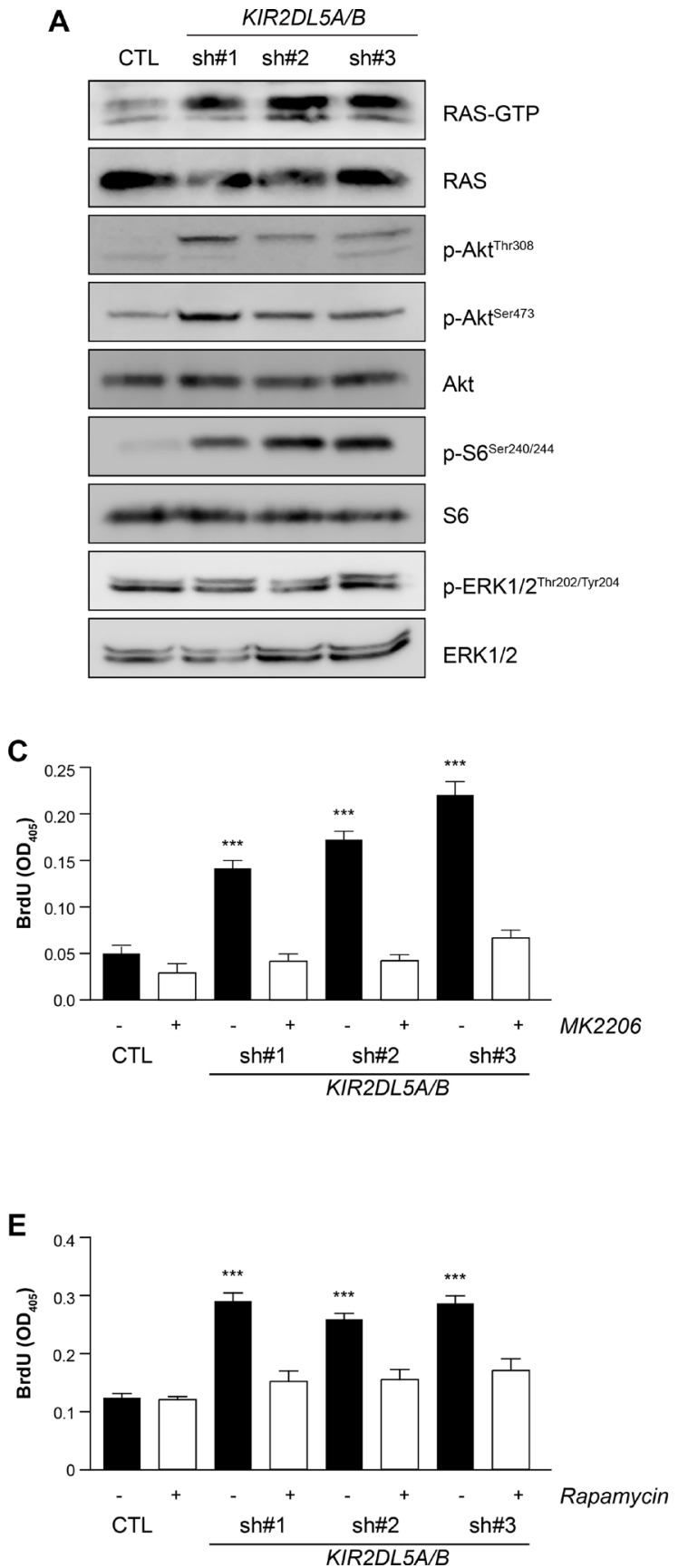

rapamycin for $4 \mathrm{~h}$. Following rapamycin exposure, there was reduced $\mathrm{AKT}^{\mathrm{Ser} 473}$ phosphorylation ( $\mathrm{sh} \# 1,0.7 ; \mathrm{sh} \# 2$ 1.1; sh\#3 1.2-fold) and S6 phosphorylation (sh\#1, 0.8; sh\#2 0.8 ; sh\#3 0.8-fold) (Supplementary Figure 5E), as well as restoration of cell numbers (Figure 4E) and proliferation (Figure 4F) to control levels. Collectively,
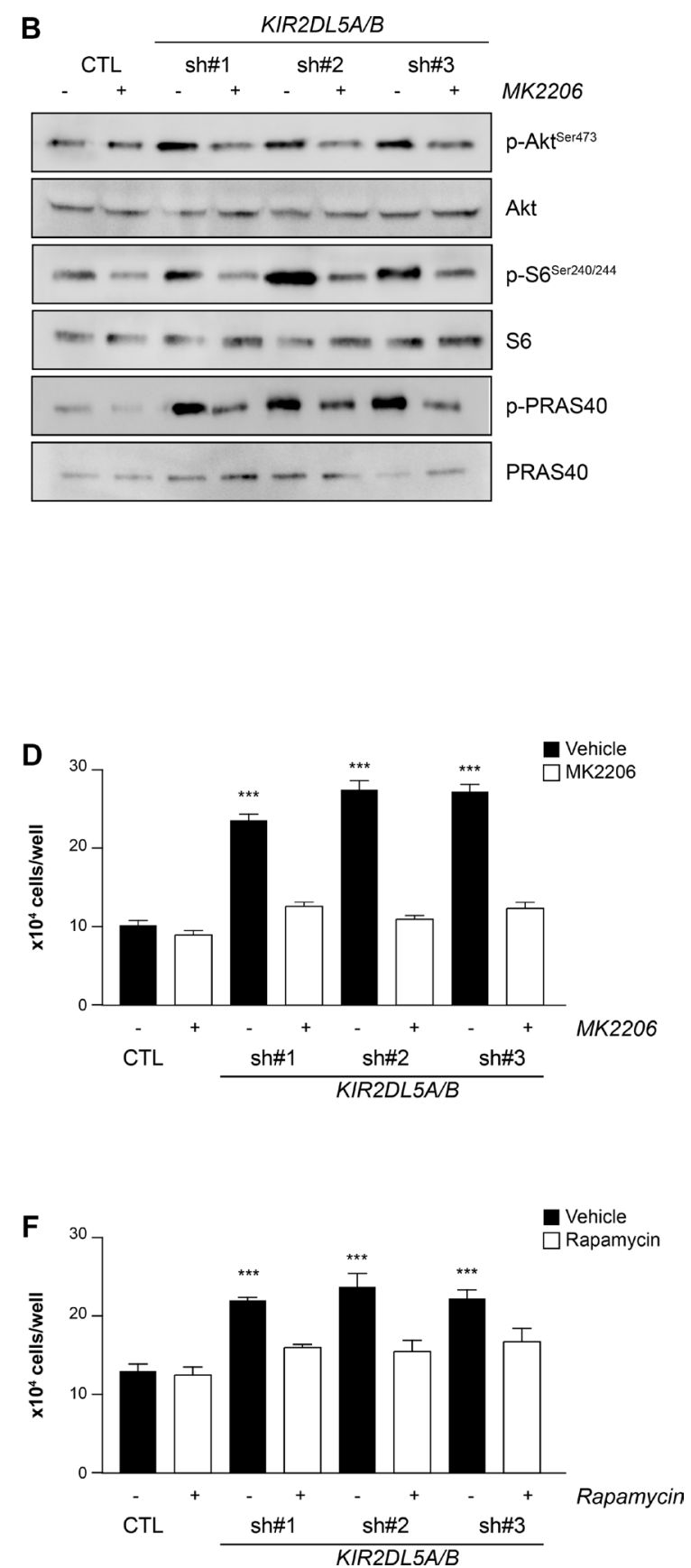

Figure 4: KIR2DL5A/B is a negative regulator of RAS/AKT signaling. (A) shRNA silencing of KIR2DL5A/B in human Schwann cells results in increased RAS activity (RAS-GTP), as well as increased AKT ${ }^{\text {Thr308 }}$, AKT ${ }^{\text {Ser473 }}$, and S6 $6^{\text {Ser240/244 }}$, but not ERK1/2 ${ }^{\text {Thr202/Tyr204, }}$ phosphorylation relative to GFP-infected Schwann cells. (B) AKT ${ }^{\text {Ser473 }}, \mathrm{S}^{\text {Ser240/244 }}$ and PRAS $40^{\text {Thr246 }}$ phosphorylation is restored to wild-type levels following MK2206 treatment of KIR2DL5A/B ${ }^{\mathrm{KD}}$ Schwann cells. $4 \mathrm{~h}$ MK2206 (C-D) or rapamycin (E-F) treatment restores (C, E) cell number and (D, F) proliferation of $K I R 2 D L 5 A / B^{\mathrm{KD}}$ Schwann cells relative to GFP-infected controls. Experiments were repeated at least three times using independently-derived cell lysates. Data are represented as means \pm s.e.m. Two-way ANOVA with Bonferroni correction was used for statistical analysis. ${ }^{* * *} p<0.001$. 
these data establish that KIR2DL5-regulated Schwann cell growth activates RTK/AKT/mTOR signaling, raising the intriguing possibility that Sp-DNFs and NF1-DNFs converge on hyperactivation of the same mitogenic signaling pathway.

RAS/AKT signaling is typically initiated by receptor tyrosine kinase (RTK) receptor engagement in Schwann cells [32-36]. In order to identify this hyperactivated RTK, a commercially-available human phospho-RTK array was employed, which recognizes 49 distinct RTKs (Figure 5A). Whereas the activity of most RTKs was not significantly altered ( $n=48$ RTK moieties), platelet-derived growth factor receptor beta (PDGFR $\beta$ ) phosphorylation was elevated (sh\#1, 3.5-; sh\#2 3.9-; sh\#3, 3.5 -fold) in $K I R 2 D L 5 A / B^{\mathrm{KD}}$ Schwann cells relative to controls. Independent validation of two of these activationspecific phosphorylation sites (PDGFR $\beta^{\text {Tyr771: }}$ sh\#1, 2-; sh\#2, 4.5-; sh\#3, 7.7-fold; and PDGFR $\beta^{\text {Tyr1009: }}$ sh\#1, 2-; sh\#2, 5.4-; sh\#3, 7.3-fold) confirmed receptor activation in KIR2DL5A/B ${ }^{\mathrm{KD}}$ Schwann cells (Figure 5B). Consistent with a dominant mechanism of action of the KIR2DL5 $N 173 D$ mutation, there was a 1.84-fold activation of PDGFR $\beta$ in KIR2DL5 N173D-expressing Schwann cells (Supplementary Figure 3). To determine the necessity of PDGFR $\beta$ activation for $K I R 2 D L 5 A / B^{\mathrm{KD}}$-mediated Schwann cell growth, we employed two different tyrosine kinase inhibitors that target PDGFR $\beta$ activation (imatinib [37-42] and sunitinib [43]), both of which are currently in clinical trials for the treatment of NF1-plexiform neurofibromas (Figure 5C-5F). Incubation of KIR2DL5A/ $B^{\mathrm{KD}}$ Schwann cells for $16 \mathrm{~h}$ with either inhibitor reduced PDGFR $\beta$ and AKT hyperactivation (Figure 5C-5D), as well as restored total cell numbers (Figure 5E) and cell proliferation (Figure 5F) to control levels.

While increased PDGFR $\beta$ activation was responsible for AKT-mediated hyperproliferation following KIR2DL5 loss, the mechanism by which KIR2DL5 regulates PDGFR $\beta$ is not clear. We hypothesize that KIR2DL5 binds PDGFR $\beta$ to restrict its activation. Consistent with this model, KIR2DL5 binds PDGFR $\beta$ in normal human Schwann cells by PDGFR $\beta$ antibodymediated immunoprecipitation. This binding is ameliorated in $K I R 2 D L 5 A / B^{\mathrm{KD}}$ Schwann cells, resulting in a 7.8-fold increase in PDGFR $\beta$ binding to PDGFR $\alpha$ (sh\#1, 5.2- ; sh\#2, 9.6- ; sh\#3, 8.7-fold increase; Figure $5 \mathrm{G})$. As such, KIR2DL5 likely inhibits PDGFR $\beta$ through direct binding, which reduces PDGFR heterodimerization, PDGFR $\beta$ phosphorylation and downstream RAS/AKTmediated Schwann cell growth (Figure 5H).

Taken together, we identified the first mutation associated with sp-DNFs. This KIR2DL5 N173D mutation is hypothesized to result in attenuated KIR2DL5 protein levels, and as such, KIR2DL5 functions as a negative regulator of Schwann cell proliferation. In this regard, KIR2DL5 reduction, resulting either from KIR2DL5 knockdown or KIR2DL5 N173D mutation, increases
Schwann cell growth in a PDGFR/AKT/mTOR-dependent mechanism. Moreover, these studies provide the first demonstration that KIR2DL5 can function outside the immune system. Finally, while the etiologic mechanisms underlying sp-DNF and NF1-DNF growth control are distinct, they share a common signaling pathway amenable to therapeutic targeting.

\section{MATERIALS AND METHODS}

\section{Tissue collection and processing}

De-identified $10 \mu \mathrm{m}$-thick sections of formalinfixed paraffin-embedded DNF tissue from 7 male patients with a confirmed NF1 diagnosis and from 10 male patients with sp-DNFs were collected from Washington University Surgical Pathology Department. Total genomic DNA was extracted following review by an experienced neuropathologist (S.D.) using a QIAamp DNA FFPE Tissue Kit (QIAGEN) following manufacturer's instructions. Genomic DNA resuspended in elution buffer was sent for exome sequencing. Since this study was performed using de-identified dermal neurofibroma specimens and the patients could not be re-consented, we were unable to obtain blood for constitutional DNA analysis.

\section{Whole-exome sequencing and filtering}

Whole human exome sequencing was performed from total genomic DNA of 17 tumors by Otogenetics Co. Briefly, library preparation was performed using an Illumina platform. Pair-ended sequencing (100 bp) with a minimum average coverage of $30 \mathrm{x}$ or $\sim 2.7-3 \mathrm{~Gb}$ was performed on a HiSeq2500 platform (human exome V5). Sequence reads were mapped to human reference genome hg18. Variants were annotated in Annovar and were filtered in Microsoft Excel to include only the following criteria: (1) Exonic variations (2) Non-synonymous variations, stop loss/ stop gain, frameshift insertions and frameshift deletions (3) 1000 genome, ExAc and ESP6500 frequencies $\leq 0.01$ (4) Deleterious variants according to SIFT, Polyphen and CADD predictions (5) Non-common polymorphism in Cosmic and ClinVar (Supplementary Table 1). Genes mutated more than twice per tumor or resulting in conservative amino acid changes were eliminated from further analysis. cBioPortal for Cancer Genomics (www.cbioportal.org) was used to search recurrent identified mutations in other cancers. The complete exome sequencing data is in the process of being uploaded to dbGaP. The sequence reads were as follows:

$\begin{array}{ccc}\text { Sample } & \text { Size } & \text { Reads } \\ \text { Sp1 } & 1,016,288,144 & 9,587,624 \\ \text { Sp2 } & 2,980,285,61 & 28,115,902 \\ \text { Sp3 } & 4,023,566,444 & 37,958,174\end{array}$




$\begin{array}{ccc}\text { Sp4 } & 2,015,092,012 & 19,010,302 \\ \text { Sp5 } & 2,763,643,024 & 26,072,104 \\ \text { Sp6 } & 2,264,326,420 & 21,361,570 \\ \text { Sp7 } & 3,049,257,056 & 28,766,576 \\ \text { Sp8 } & 2,111,053,38 & 19,915,598 \\ \text { Sp9 } & 850,889,772 & 8,027,262 \\ \text { Sp10 } & 4,016,548,608 & 37,891,968 \\ \text { NF1-1 } & 1,752,023,756 & 16,528,526 \\ \text { NF1-2 } & 3,296,901,464 & 31,102,844 \\ \text { NF1-3 } & 2,697,579,372 & 25,448,862 \\ \text { NF1-4 } & 2,130,578,164 & 20,099,794 \\ \text { NF1-5 } & 1,632,340,852 & 15,399,442 \\ \text { NF1-6 } & 1,685,491,160 & 15,900,860 \\ \text { NF1-7 } & 2,751,629,620 & 25,958,770\end{array}$

\section{Immunohistochemistry and immunofluorescence}

Paraffin-embedded tonsil, 4 normal peripheral nerves (sural nerve), 23 NF1-DNFs (13 males, 10 females) and 55 sp-DNFs (31 males, 24 females) were included in the immunohistochemical analyses. All DNFs were incubated with neurofibromin (Santa Cruz sc-67) antibodies, while and all DNFs, tonsil and normal sural nerve sections were incubated with KIR2DL5 (Abcam; ab175895) antibodies. Biotinylated secondary rabbit antibodies (Vector Laboratories) were used in combination with Vectastain Elite ABC development and hematoxylin counterstaining. Normal human tonsil was used as the reference control tissue for the KIR2DL5 antibody. Images were acquired on a Nikon Eclipse E600 microscope conjugated with a Nikon Plan Fluor 10x/0.30 DIC L objective and a Leica EC3 camera. Normal human sural nerve, sp-DNF sections, as well as primary cell cultures of normal human Schwann cells and HEK293T cells were analyzed by immunofluorescence using S100 $\beta$ (Millipore CB1040), c-Kit (Millipore; MAB1164), tryptase (Abcam; ab2378), vimentin (DSHB; AMF-17b) and KIR2DL5 (Abcam; ab129751) antibodies conjugated to appropriate Alexa Fluor secondary antibodies. Images were acquired on a Nikon Eclipse TE300 fluorescence microscope conjugated with a Nikon Plan Fluor 20x/0.45 ELWD objective and a Leica DFC3000G camera.

\section{Normal human Schwann cell culture, lentiviral infection and pharmacological inhibitor treatments}

Normal human Schwann cells (ScienCell Research Laboratories) were cultured on poly-L-lysine-coated plates in Schwann cell medium (ScienCell \#1701) supplemented with Schwann cell growth factors, Pen/Strep and fetal bovine serum (FBS), unless otherwise stated and were maintained as per the manufacturer's instructions. For serum-starvation experiments (Supplementary Figure 5), Schwann cells were plated on poly-L-lysine-coated plates in the presence of serum (FBS) for 16h, followed by a $36 \mathrm{~h}$ period of serum deprivation during which cells were cultured only in Schwann cell medium supplemented with Schwann cell growth factors and Pen/Strep. 10\% FBS was added to the cells for 2, 5, 15, 30 or 60 minutes at which time points cells were collected for western blotting analysis.

Three sets of lentiviral infection experiments were performed. Schwann cells were either infected once with lentivirus particles encoding (1) either a KIR $2 D L 5^{\mathrm{wT}}$ control or KIR2DL5N173D to establish the effect of the identified mutation on normal Schwann cells (Figure 2), (2) either a GFP-control or shKIR2DL5 RNA to knock down KIR2DL5 expression (Figures 3-5), or were infected twice with lentiviral preparations encoding (3) both a GFP control and KIR2DL5 ${ }^{\mathrm{CTL}}$ control or both shKRI2DL5 RNA and KIR2DL5 $5^{\mathrm{CTL}}$ to confirm the specificity of the shKIR2DL5 RNA constructs (Supplementary Figure 4). For all lentiviral infections, HEK-293T cells were initially cultured in DMEM (Gibco) supplemented with 10\% heat-inactivated FBS and 1\% Pen/Strep solution (Gibco). Three micrograms of total DNA was transfected per well of a 6-well plate $(1.5 \mu \mathrm{g}$ KIR2DL5WT, KIR2DL5CTL KIR2DL5N173D, shKIR2DL5 or pLKO-GFP control; $1.5 \mu \mathrm{g}$ lentiviral packaging constructs) using Fugene HD reagent (Promega) following manufacturer's instructions. 24h post transfection the media was replaced with fresh Schwann cell media supplemented with10\% FBS, Schwann cell growth factors and antibiotics. Viral preparations were collected at 48 and $72 \mathrm{~h}$ posttransfection, were filtered, supplemented with polybrene and used for direct infections of Schwann cells. The sequences of the siRNA constructs were:

shKIR2DL5 \#1: TCTCTCCATGACTCACCCTAT; shKIR2DL5 \#2: CAGGAGCTCATTTGACATGTA; shKIR2DL5 \#3: GAAACTCTTCAAGTAGTTCAT; KIR2DL5 ${ }^{\mathrm{WT}}$ cDNA cloned in a lentiviral vector was purchased from Origene and was either directly transfected into HEK293T cells, or was transfected following sitedirected mutagenesis with QuikChange Site-Directed mutagenesis kit (Promega) following manufacturer's instructions in order to generate KIR2DL5 ${ }^{\text {CTL }}$ (harboring six distinct base pair mutations within the short hairpin recognition sequences but resulting in identical amino acid sequence) or KIR2DL5 ${ }^{\mathrm{N} 173 \mathrm{D}}$. All resulting constructs were subcloned and sequenced by Genewiz. The following primers were used to generate the expression constructs: KIR2DL5 ${ }^{\mathrm{CTL} 1}$ (Forward: 5'-GA GCTTGGTTCAGTGGGTGAAGAAGAGCTGCTCGA GGAATTTCCTGTGACAGAAACAAGCAGTGG-3', Reverse: 5'-CCACTGCTTGTTTCTGTCACAGGAAA TTCCTCGAGCAGCTCTTCTTCACCCACTGAACCA AGCTC-3'); KIR2DL5 ${ }^{\text {CTL2 }}$ (Forward: 5'- CCTACACAT 


\section{A}

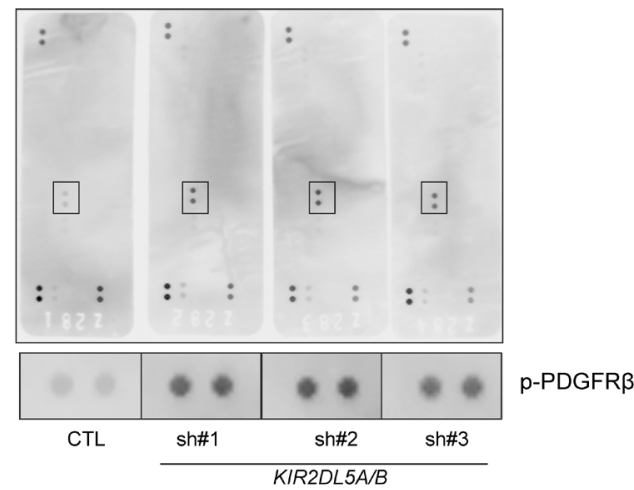

C

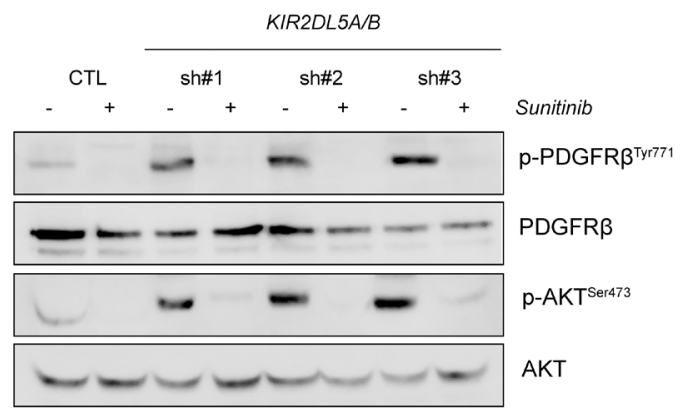

E

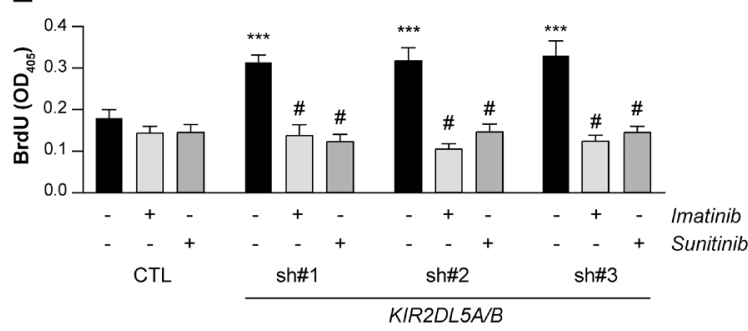

G

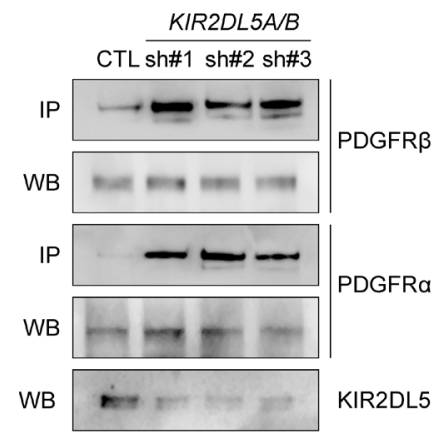

B

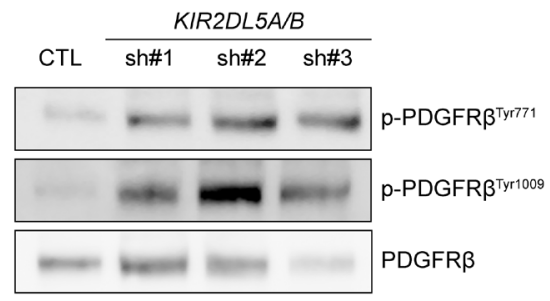

D

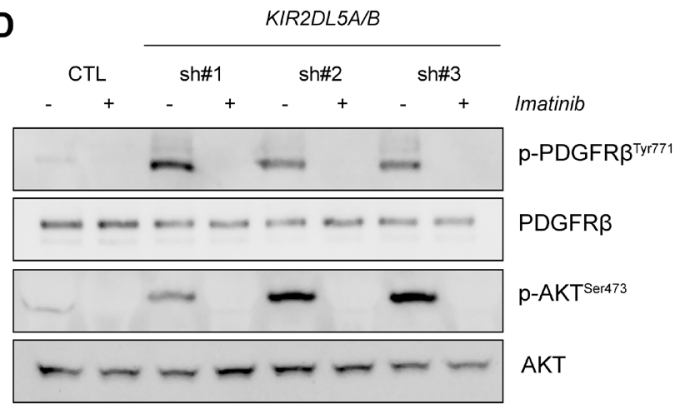

$\mathbf{F}$

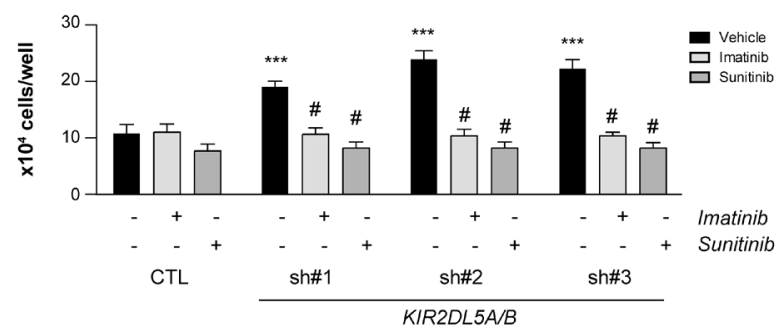

H

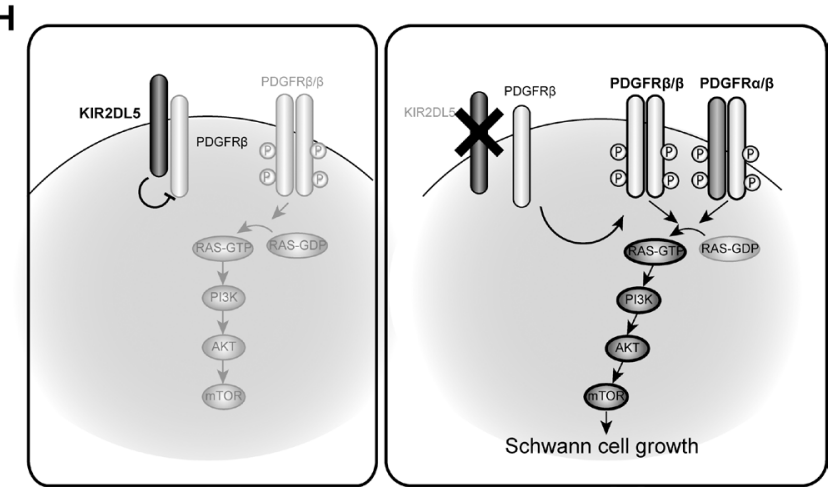

Figure 5: KIR2DL5A/B inhibits Schwann cell proliferation in a PDGFRß/AKT-dependent manner. (A) PDGFR $\beta$ is hyperphosphorylated following silencing of KIR2DL5 in normal human Schwann cells as demonstrated with a human phospho-RTK array. (B) PDGFR $\beta^{\text {Ty } y 771}$ and PDGFR $\beta^{\text {Tyr 1009 }}$ phosphorylation is increased following KIR2DL5A/B silencing. Inhibition of aberrant PDGFR $\beta$ and AKT phosphorylation following $16 \mathrm{~h}$ imatinib $(\mathbf{C})$ or sunitinib (D) treatment restores cell numbers $(\mathbf{E})$ and proliferation $(\mathbf{F})$ to control levels. Data are represented as means \pm s.e.m. All experiments were repeated at least three times. Two-way ANOVA with Bonferroni correction was used for statistical analysis. ${ }^{* * *} p<0.001$ compared to vehicle control, $p<0.001$ compared to vehicle sh\#1, sh\#2, $\operatorname{sh} \# 3$, respectively. (G) KIR2DL5A/B silencing leads to increased PDGFR $\beta / P D G F R \alpha$ binding, as assessed by immunoprecipitation. (H) The proposed model of KIR2DL5 growth regulation envisions that KIR2DL5 normally binds and sequesters PDGFR $\beta$, such that KIR2DL5 loss leads to increased PDGFR $\alpha / \beta$ binding and RAS/AKT-mediated hyperproliferation. 
GCTTCGGCTCGTTACATGATTCACCGTACGAGTG

GTCAGACCCGAGTG-3', Reverse: 5-CACTCGG GTCTGACCACTCGTACGGTGAATCATGTAACGAGC CGAAGCATGTGTAGG-3'); KIR2DL5 ${ }^{\mathrm{N} 173 \mathrm{D}}$ (Forward: 5'-CCTGGAATGTTCCATCGACGCTGGGCACTGC-3'; Reverse: 5'-GCAGTGCCCAGCGTCGATGGAACAT TCCAGG-3').

GFP control- or siRNA-infected Schwann cells underwent treatment with the following reagents: MK2206 (50nM in DMSO, $4 \mathrm{~h}$; Selleckchem), rapamycin $(10 \mu \mathrm{M}$ in DMSO, $4 \mathrm{~h}$; Selleckchem), imatinib (10 $\mu \mathrm{M}$ in water, 16h; Sigma), sunitinib (10 $\mu$ M in DMSO, 16 h; Sigma), or PD0325901 (10 nM in DMSO, 4h; Selleckchem).

\section{Western blotting, immunoprecipitation, RTK arrays and RAS/RAS pathway activity assays}

Western blotting was performed on Schwann cells lysed in buffer containing 1\% NP-40 (nonyl phenoxypolyethoxylethanol), supplemented with protease and phosphatase inhibitors using KIR2DL5 (Abcam), $\alpha-$ tubulin (Sigma), RAS (Millipore), phospho-AKT ${ }^{\text {Thr308, }}$ phospho-AKT ${ }^{\text {Ser773 }}$, AKT, phospho-- 66 Ser240/244, S6, phospho-

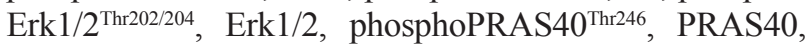
phospho-PDGFR $\beta^{\text {Tyr771 }}$, phospho-PDGFR $\beta^{\text {Tyr1009 }}$, PDGFR $\beta$, PDGFR $\alpha$ (Cell Signaling) primary antibodies, as well as HRP-conjugated secondary antibodies (Cell Signaling) and ECL (Fisher) chemiluminescence. Western signal band intensity was quantified using ImageJ Software (National Institutes of Health, USA, http://imagej.nih.gov/ij Java 1.7.0_67). KIR2DL5A/BKD cell KIR2DL5 expression levels (Figures 2A, 3D) were calculated by normalizing the relative KIR2DL5/ $\alpha$-tubulin band intensity ratio to that of GFPcontrol-infected Schwann cells. For the immunoprecipitation studies, $100 \mu \mathrm{g}$ total Schwann cell protein lysate was precleared for $1 \mathrm{~h}$ in agarose protein $\mathrm{G}$ beads (Cell Signaling), immunoprecipitated with PDGFR $\beta$ overnight and collected with agarose protein $\mathrm{G}$ beads for 2 hours. For the human phospho-RTK array (human phospho-receptor tyrosine kinase array kit; R\&D Systems) Schwann cells were lysed in the provided buffer and $80 \mu \mathrm{g}$ total protein was assayed using manufacturer's instructions. In brief, the assay can detect phosphorylation of the following RTKs: ALK/ CD246, EphB4, MuSK, Axl, EphB6, PDGFRa, DDR1, ErbB2, PDGFR $\beta$, DDR2, ErbB3, c-Ret, Dtk, ErbB4, ROR1, EGFR, FGFR1, ROR2, EphA1, FGFR2 $\alpha$, Ryk, EphA2, FGFR3, SCFR/c-kit, EphA3, FGFR4, Tie-1, EphA4, Flt3/Flk-2, Tie-2, EphA5, HGFR/c-MET, TrkA, EphA6, IGF1R, TrkB, EphA7, Insulin R/CD220, TrkC, EphA10, M-CSFR, VEGFR1/Flt-1, EphB1, Mer, VEGFR2/KDR, EphB2, MSPR/Ron, VEGFR3/Flt-4, and EphB3. Since only PDGFR $\beta$ was hyperphosphorylated, the activation was independently validated with two separate phosphoPDGFR $\beta$ antibodies: phospho-PDGFR $\beta^{\text {Tyr771 }}$, phospho-

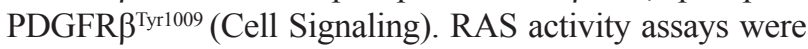
performed following Rafl-RBD immunoprecipitation using manufacturer's instructions (RAS activation kit; Millipore). All experiments were repeated at least three times using independently derived cell lysates.

\section{Proliferation and apoptosis assays}

Schwann cell proliferation and TUNEL staining were assessed using the BrdU Cell Proliferation Colorimetric ELISA kit (Roche) or the TUNEL staining kit (Roche) following manufacturer's instructions. For both assays, Schwann cells were seeded at 5000 cells/ well of a 96-well plate. For the proliferation assays, Schwann cells were serum-starved for 24 hours, if treated, incubated in vehicle or appropriate inhibitors for a total of 24 hours, labelled with BrdU for $18 \mathrm{~h}$ followed by $90 \mathrm{~min}$ incubation in peroxidase-conjugated anti-BrdU antibody. The optical density of the cells was measured at $405 \mathrm{~nm}$ on a BioRad spectrophotometer. For the TUNEL assay, cells were incubated in serum-containing media for $24 \mathrm{~h}$ before being fixed in 4\% PFA, incubated in TUNEL substrate for $1 \mathrm{~h}$ and imaged using a fluorescent microscope.

\section{Statistical analyses}

All statistical tests were performed using GraphPad Prism 5 software. Student's $t$-test, one-way or two-way analysis of variance (ANOVA) with Bonferroni post-test correction was employed for all experiments.

\section{Authors' contributions}

C.A., S.D., and D.H.G. designed the experiments and wrote the manuscript. C.A. performed the experiments. S.D. provided neuropathological assessments and tumor specimens.

\section{ACKNOWLEDGMENTS}

We appreciate the informatics advice provided by Drs. Mukesh Sharma and Madhurima Kaushal (Washington University).

\section{CONFLICTS OF INTEREST}

The authors declare no competing financial interests.

\section{FUNDING}

This work was funded by a grant from The Giorgio Foundation.

\section{REFERENCES}

1. Scheithauer BW WJ, Erlandson RA. (1999). Atlas of tumor pathology. Tumors of the peripheral nervous system. 
2. Chen Z, Liu C, Patel AJ, Liao CP, Wang Y, Le LQ. Cells of origin in the embryonic nerve roots for NF1-associated plexiform neurofibroma. Cancer Cell. 2014; 26:695-706.

3. Le LQ, Liu C, Shipman T, Chen Z, Suter U, Parada LF. Susceptible stages in Schwann cells for NF1-associated plexiform neurofibroma development. Cancer Res. 2011; 71:4686-95.

4. Le LQ, Shipman T, Burns DK, Parada LF. Cell of origin and microenvironment contribution for NF1-associated dermal neurofibromas. Cell Stem Cell. 2009; 4:453-63.

5. Rutkowski JL, Wu K, Gutmann DH, Boyer PJ, Legius E. Genetic and cellular defects contributing to benign tumor formation in neurofibromatosis type 1 . Hum Mol Genet. 2000; 9:1059-66.

6. Sawada S, Florell S, Purandare SM, Ota M, Stephens K, Viskochil D. Identification of NF1 mutations in both alleles of a dermal neurofibroma. Nat Genet. 1996; 14:110-2.

7. Serra E, Puig S, Otero D, Gaona A, Kruyer H, Ars E, Estivill X, Lazaro C. Confirmation of a double-hit model for the NF1 gene in benign neurofibromas. Am J Hum Genet. 1997; 61:512-9.

8. Kim HA, Ling B, Ratner N. Nf1-deficient mouse Schwann cells are angiogenic and invasive and can be induced to hyperproliferate: reversion of some phenotypes by an inhibitor of farnesyl protein transferase. Mol Cell Biol. 1997; 17:862-72.

9. Kim HA, Rosenbaum T, Marchionni MA, Ratner N, DeClue JE. Schwann cells from neurofibromin deficient mice exhibit activation of p21ras, inhibition of cell proliferation and morphological changes. Oncogene. 1995; 11:325-35.

10. Sherman LS, Atit R, Rosenbaum T, Cox AD, Ratner N. Single cell Ras-GTP analysis reveals altered Ras activity in a subpopulation of neurofibroma Schwann cells but not fibroblasts. J Biol Chem. 2000; 275:30740-5.

11. Johannessen CM, Reczek EE, James MF, Brems H, Legius E, Cichowski K. The NF1 tumor suppressor critically regulates TSC2 and mTOR. Proc Natl Acad Sci U S A. 2005; 102:8573-8.

12. Johansson G, Mahller YY, Collins MH, Kim MO, Nobukuni T, Perentesis J, Cripe TP, Lane HA, Kozma SC, Thomas G, Ratner N. Effective in vivo targeting of the mammalian target of rapamycin pathway in malignant peripheral nerve sheath tumors. Mol Cancer Ther. 2008; 7:1237-45.

13. Varin J, Poulain L, Hivelin M, Nusbaum P, Hubas A, Laurendeau I, Lantieri L, Wolkenstein P, Vidaud M, Pasmant E, Chapuis N, Parfait B. Dual mTORC1/2 inhibition induces anti-proliferative effect in NF1-associated plexiform neurofibroma and malignant peripheral nerve sheath tumor cells. Oncotarget. 2016; 7:35753-67. doi: 10.18632/oncotarget.7099.

14. Wu J, Dombi E, Jousma E, Scott Dunn R, Lindquist D, Schnell BM, Kim MO, Kim A, Widemann BC, Cripe TP,
Ratner N. Preclincial testing of sorafenib and RAD001 in the $\mathrm{Nf}$ (flox/flox) ; DhhCre mouse model of plexiform neurofibroma using magnetic resonance imaging. Pediatr Blood Cancer. 2012; 58:173-80.

15. Messiaen LM, Callens $\mathrm{T}$, Mortier G, Beysen D, Vandenbroucke I, Van Roy N, Speleman F, Paepe AD. Exhaustive mutation analysis of the NF1 gene allows identification of $95 \%$ of mutations and reveals a high frequency of unusual splicing defects. Hum Mutat. 2000; 15:541-55.

16. Messiaen LM, Wimmer K. Pitfalls of automated comparative sequence analysis as a single platform for routine clinical testing for NF1. J Med Genet. 2005; 42: e25.

17. Storlazzi CT, Von Steyern FV, Domanski HA, Mandahl N, Mertens F. Biallelic somatic inactivation of the NF1 gene through chromosomal translocations in a sporadic neurofibroma. Int J Cancer. 2005; 117:1055-7.

18. Jacoby LB, MacCollin M, Barone R, Ramesh V, Gusella JF. Frequency and distribution of NF2 mutations in schwannomas. Genes Chromosomes Cancer. 1996; 17:45-55.

19. Twist EC, Ruttledge MH, Rousseau M, Sanson M, Papi L, Merel P, Delattre O, Thomas G, Rouleau GA. The neurofibromatosis type 2 gene is inactivated in schwannomas. Hum Mol Genet. 1994; 3:147-51.

20. Piotrowski A, Xie J, Liu YF, Poplawski AB, Gomes AR, Madanecki $\mathrm{P}, \mathrm{Fu} \mathrm{C}$, Crowley MR, Crossman DK, Armstrong L, Babovic-Vuksanovic D, Bergner A, Blakeley JO, et al. Germline loss-of-function mutations in LZTR1 predispose to an inherited disorder of multiple schwannomas. Nat Genet. 2014; 46:182-7.

21. Smith MJ, Isidor B, Beetz C, Williams SG, Bhaskar SS, Richer W, O’Sullivan J, Anderson B, Daly SB, Urquhart JE, Fryer A, Rustad CF, Mills SJ, et al. Mutations in LZTR1 add to the complex heterogeneity of schwannomatosis. Neurology. 2015; 84:141-7.

22. Hulsebos TJ, Plomp AS, Wolterman RA, RobanusMaandag EC, Baas F, Wesseling P. Germline mutation of INI1/SMARCB1 in familial schwannomatosis. Am J Hum Genet. 2007; 80:805-10.

23. Hutter S, Piro RM, Reuss DE, Hovestadt V, Sahm F, Farschtschi S, Kehrer-Sawatzki H, Wolf S, Lichter P, von Deimling A, Schuhmann MU, Pfister SM, Jones DT, et al. Whole exome sequencing reveals that the majority of schwannomatosis cases remain unexplained after excluding SMARCB1 and LZTR1 germline variants. Acta Neuropathol. 2014; 128:449-52.

24. Rajalingam R, Parham P, Abi-Rached L. Domain shuffling has been the main mechanism forming new hominoid killer cell Ig-like receptors. J Immunol. 2004; 172:356-69.

25. Vilches C, Rajalingam R, Uhrberg M, Gardiner CM, Young NT, Parham P. KIR2DL5, a novel killer-cell receptor with a D0-D2 configuration of Ig-like domains. J Immunol. 2000; 164:5797-804.

26. Vilches C, Parham P. KIR: diverse, rapidly evolving receptors of innate and adaptive immunity. Annu Rev Immunol. 2002; 20:217-51. 
27. Belkin D, Torkar M, Chang C, Barten R, Tolaini M, Haude A, Allen R, Wilson MJ, Kioussis D, Trowsdale J. Killer cell Ig-like receptor and leukocyte Ig-like receptor transgenic mice exhibit tissue- and cell-specific transgene expression. J Immunol. 2003; 171:3056-63.

28. Rajagopalan S, Long EO. A human histocompatibility leukocyte antigen (HLA)-G-specific receptor expressed on all natural killer cells. J Exp Med. 1999; 189:1093-100.

29. Yusa S, Catina TL, Campbell KS. KIR2DL5 can inhibit human NK cell activation via recruitment of Src homology region 2-containing protein tyrosine phosphatase-2 (SHP2). J Immunol. 2004; 172:7385-92.

30. Jessen WJ, Miller SJ, Jousma E, Wu J, Rizvi TA, Brundage ME, Eaves D, Widemann B, Kim MO, Dombi E, Sabo J, Hardiman Dudley A, Niwa-Kawakita M, et al. MEK inhibition exhibits efficacy in human and mouse neurofibromatosis tumors. J Clin Invest. 2013; 123:340-7.

31. Jousma E, Rizvi TA, Wu J, Janhofer D, Dombi E, Dunn RS, Kim MO, Masters AR, Jones DR, Cripe TP, Ratner N. Preclinical assessments of the MEK inhibitor PD-0325901 in a mouse model of Neurofibromatosis type 1. Pediatr Blood Cancer. 2015; 62:1709-16.

32. Ammoun S, Flaiz C, Ristic N, Schuldt J, Hanemann CO. Dissecting and targeting the growth factor-dependent and growth factor-independent extracellular signal-regulated kinase pathway in human schwannoma. Cancer Res. 2008; 68:5236-45.

33. Chen S, Burgin S, McDaniel A, Li X, Yuan J, Chen M, Khalaf W, Clapp DW, Yang FC. Nf1-/- Schwann cellconditioned medium modulates mast cell degranulation by c-Kit-mediated hyperactivation of phosphatidylinositol 3-kinase. Am J Pathol. 2010; 177:3125-32.

34. Kwon YK, Bhattacharyya A, Alberta JA, Giannobile WV, Cheon K, Stiles CD, Pomeroy SL. Activation of ErbB2 during wallerian degeneration of sciatic nerve. J Neurosci. 1997; 17:8293-9.

35. Miller SJ, Li H, Rizvi TA, Huang Y, Johansson G, Bowersock J, Sidani A, Vitullo J, Vogel K, Parysek LM, DeClue JE, Ratner N. Brain lipid binding protein in axon-Schwann cell interactions and peripheral nerve tumorigenesis. Mol Cell Biol. 2003; 23:2213-24.
36. Yamauchi J, Miyamoto Y, Tanoue A, Shooter EM, Chan JR. Ras activation of a Rac1 exchange factor, Tiam1, mediates neurotrophin-3-induced Schwann cell migration. Proc Natl Acad Sci U S A. 2005; 102:14889-94.

37. Demestre M, Herzberg J, Holtkamp N, Hagel C, Reuss D, Friedrich RE, Kluwe L, Von Deimling A, Mautner VF, Kurtz A. Imatinib mesylate (Glivec) inhibits Schwann cell viability and reduces the size of human plexiform neurofibroma in a xenograft model. J Neurooncol. 2010; 98:11-9.

38. Robertson KA, Nalepa G, Yang FC, Bowers DC, Ho CY, Hutchins GD, Croop JM, Vik TA, Denne SC, Parada LF, Hingtgen CM, Walsh LE, Yu M, et al. Imatinib mesylate for plexiform neurofibromas in patients with neurofibromatosis type 1: a phase 2 trial. Lancet Oncol. 2012; 13:1218-24.

39. Yang FC, Ingram DA, Chen S, Zhu Y, Yuan J, Li X, Yang X, Knowles S, Horn W, Li Y, Zhang S, Yang Y, Vakili ST, et al. Nf1-dependent tumors require a microenvironment containing Nf1+/- and c-kit-dependent bone marrow. Cell. 2008; 135:437-48.

40. Aoki M, Nabeshima K, Koga K, Hamasaki M, Suzumiya J, Tamura K, Iwasaki H. Imatinib mesylate inhibits cell invasion of malignant peripheral nerve sheath tumor induced by platelet-derived growth factor-BB. Lab Invest. 2007; 87:767-79.

41. Ohishi J, Aoki M, Nabeshima K, Suzumiya J, Takeuchi T, Ogose A, Hakozaki M, Yamashita Y, Iwasaki H. Imatinib mesylate inhibits cell growth of malignant peripheral nerve sheath tumors in vitro and in vivo through suppression of PDGFR-beta. BMC Cancer. 2013; 13: 224.

42. Perrone F, Da Riva L, Orsenigo M, Losa M, Jocolle G, Millefanti C, Pastore E, Gronchi A, Pierotti MA, Pilotti S. PDGFRA, PDGFRB, EGFR, and downstream signaling activation in malignant peripheral nerve sheath tumor. Neuro Oncol. 2009; 11:725-36.

43. Ferguson MJ, Rhodes SD, Jiang L, Li X, Yuan J, Yang X, Zhang S, Vakili ST, Territo P, Hutchins G, Yang FC, Ingram DA, Clapp DW, et al. Preclinical Evidence for the Use of Sunitinib Malate in the Treatment of Plexiform Neurofibromas. Pediatr Blood Cancer. 2016; 63:206-13. 